\title{
EFFECT OF PLANT POPULATION, ORGANIC FERTILIZATION AND NITROGEN LEVELS ON GROWTH AND YIELD OF MAIZE

\author{
Rasha S.A. EL-Moursy ${ }^{*}$ \\ *Agronomy Department, Faculty of Agriculture, Mansoura University. \\ ** Under- Secretary of Ministry of Agriculture for Seed Production.
} \\ Leilah, A. A. ${ }^{*}$; M. A. Badawi ${ }^{*}$; M. I. EL-Emery ${ }^{* *}$ and
}

\begin{abstract}
Two field experiments were performed at the Experimental Station, Faculty of Agriculture, Mansoura University, during the two successive summer seasons of 2006 and 2007. The main objectives of this study were to determine the effect of organic fertilization (compost) doses, plant population (hill spacing) and nitrogen fertilizer levels on growth, yield and its components of maize (Zea mays L.) Single Cross Hybrid Pioneer 30 K 9 (S.C.H.P. 30 K 9). A strip split plot design with four replicates was used. The obvious results of this investigation can be summarized as follows:

- All studied characters were significantly improved by applying organic fertilization (compost) doses in both seasons. highest values of maize growth and productivity parameters were obtained by the application of organic fertilization(compost)at $4 \mathrm{t} / \mathrm{fed}$ in both seasons.

- Increasing plant spacings up to $30 \mathrm{~cm}$ between hills (20 000 plant/fed) increased all studied characters, except number of days from sowing to $50 \%$ tasseling and plant height, which increased due to sowing maize in hills $20 \mathrm{~cm}$ apart $(30000$ plants/fed) in both seasons. Sowing maize plants in hills $25 \mathrm{~cm}$ apart (medium space i.e. 24000 plants/fed) surpassed other plant spacings in grain yield (ardab/fed) in both seasons.

- Application nitrogen fertilization at the level of $125 \mathrm{~kg} \mathrm{~N} / \mathrm{fed}$ significantly exceeded other studied levels $(50,75$ and $100 \mathrm{~kg} \mathrm{~N} / \mathrm{fed})$ with respect to their effect on all the studied growth parameters and yield components as well as grain yield of maize in both seasons.

Generally, it can be concluded that according to the obtained results from this study, sowing maize Single Cross Hybrid Pioneer $30 \mathrm{~K} 9$ plants at $25 \mathrm{~cm}$ space between hills (24 000 plant/fed) and adding $4 \mathrm{t} / \mathrm{fed}$ compost as well as 100 or $125 \mathrm{~kg}$ $\mathrm{N} /$ fed can be consider the best treatment for raising maize productivity under the environmental conditions of El-Mansoura region.
\end{abstract}

\section{INTRODUCTION}

Maize (Zea mays L.) is the most widely grown crop in many countries in the world. Maize is a major source of starch and in many industrialized food products. It is also a major source of cooking oil (corn oil). Maize is also widely grown to feed livestock, as forage, silage or grain. In Egypt, maize is considered as one of the main cereal crops, comes the third after wheat and rice. Maize is very essential either for the human food or animal feeding and a common ingredient for industrial products. Consequently, a great attention should be paid to increase maize productivity by maximizing yield per unit area in order to reduce the gab between its production and consumption. Since, maize is well known for its high demand for nutrients and other production inputs. Thereby, among factors that may be 
Leilah, A. A. et al.

improveme maize productivity organic fertilization (compost) doses, plant population (hill spacing) and nitrogen fertilizer levels.

The use of organic fertilization as compost in agriculture are practiced in Egypt recently. The role of organic fertilization (compost) is improving soil organic matter, nitrogen content, $\mathrm{P}_{2} \mathrm{O}_{5}$ concentration and exchangeable cations. Furthermore decreasing soil $\mathrm{pH}$, which result in increasing solubility of nutrients and nutrient availability to the plants hence enhancement plant growth and development as well as gradually increasing grain yields of maize (Salem, 1988 and Ali et al., 2003). Toderi et al. (1999) showed that the use of organic materials (maize and wheat straw) improved soil organic matter, nitrogen content, $\mathrm{P}_{2} \mathrm{O}_{5}$ concentration, exchangeable cations and apart of $\mathrm{Fe}$ consequently enhancement plant growth and development as well as yield. Fatma, Nofal et al. (2005) noticed that applying $10 \mathrm{~m}^{3} / \mathrm{fed}$ of chicken manure or rice straw compost increased maize grain yield as compared with the control treatment (without organic manure). This increment may be attributed to that organic manure contains of microorganisms which fix and release phytohormones, which stimulate plant growth. Sheng, Mao et al. (2006) showed that farmyard manure supplies adequate amounts of nutrients such as $\mathrm{N}$ and $\mathrm{K}$ which tended to balance crop requirements and resulted in improving grain yield of maize. El-Hamdi et al. (2008) revealed that the highest values of ear diameter, 100 - grain weight and grain yield were obtained from fertilization with $10 \mathrm{~m} 3$ of chicken manure/fed.

As maize do not have tillering capacity to adjust to variation in plant stand, optimum plant population for grain production are important. Thus, to increase grain yield, it must be planted maize at proper plant population. Samira et al. (2000) concluded that the highest values of 100-kernel weight, and grain yield (ardab/fed) were obtained at hill space of $25 \mathrm{~cm}$ expressed 24000 plants/fed. El-Far (2001) found that number of days from sowing to 50 $\%$ tasseling and silking, plant height and ear height were significantly increased with increasing the density to 30000 plants/fed $(20 \mathrm{~cm}$ apart) in both seasons. Vice-versa, stem diameter, ear leaf area, ear length, ear diameter, number of grains/row, 100-grain weight and grain yield/plant were significantly increased by increasing plant density to 20000 plants $/ \mathrm{fed}(30 \mathrm{~cm}$ apart) in both seasons. Sharief (2001) showed that increasing plant population density of maize to $20-30$ thosund plants/fed, or sowing maize in narrow row sapcing $51-60 \mathrm{~cm}$ and hill spacing of $25-30 \mathrm{~cm}$ apart gave optimum plant density for maximizing grain yield per unit area depending on density pattern, sowing date, soil fertility and cultivars.

Maize requires high nitrogen amounts to warrant high yields. Where nitrogen plays a key role in plant nutrition. It is the mineral element that required in the greatest quantity by cereal crop plants especially maize and it is the nutrient most often deficit in the Egyptian soils. Thus, increasing application of nitrogen fertilizer levels led to significant increases in growth, yield and its components of maize crop (Cox and Cherney, 2001 ; El-Far, 2001 ; El-Murshedy, 2002 ; El-Mahdy, Amal, 2003 ; Toaima and Saleh, 2003; Abd-Alla, 2005 ; Samira, Hussein, 2005 ; Atia and Mahmoud, 2006 ; Seadh and El-Zehery, 2007 ; Abdel-Hafez et al., 2008 and El-Hamdi et al., 2008). In 
spit of mineral fertilizers have a good effect on plant productivity, Schroder et al. (2000) stated that high nitrogen application rates are used by maize growers as an insurance, but may have an adverse effect on the environment. Therefore, it must be adjusted application of nitrogen rates to the amounts of soil mineral nitrogen present shortly before planting.

Thus, this study was aimed to determine the effect of organic fertilization (compost) doses, hill spacing and nitrogen fertilizer levels as well as their interactions on growth, yield and its components of maize Single Cross Pioneer $30 \mathrm{~K} 9$ (S.C.P. $30 \mathrm{~K}$ 9) under the environmental conditions of Mansoura district.

\section{MATERIALS AND METHODS}

Two field experiments were performed at the Experimental Station, Faculty of Agriculture, Mansoura University, during 2006 and 2007 seasons to determine the effect of organic fertilization (compost) doses, hill spacing (plant population) and nitrogen fertilizer levels on growth, yield and its components of maize (Zea mays L.) Single Cross Hybrid Pioneer $30 \mathrm{~K} 9$ (S.C.H.P. $30 \mathrm{~K}$ 9).

The experiments were laid-out in a strip split plot design with four replicates. The vertical plots were assigned to three organic fertilization (compost) doses i.e. 0, 2 and 4 t/fed compost. After soil preparation, ridging and determining experimental plots of organic fertilization (compost) doses, ridges were leveled and then aforementioned doses of compost were added, finally, ridging was performed again. Chemical analysis of used compost was shown in Table 2.

Table 1: Chemical analysis of used compost.

\begin{tabular}{|c|c|c|c|}
\hline Analysis & Result & Analysis & Result \\
\hline Color & Dark brown & Nitrate nitrogen (ppm) & 27 \\
\hline Odor & Accepted & Organic matter (\%) & 36.56 \\
\hline Texture & Spongy & Organic carbon (\%) & 20.84 \\
\hline Seed weeds & Nil & Ash (\%) & 63.44 \\
\hline Nematodes & Nil & C : N ratio & $16.8: 1$ \\
\hline Wet weight $\left(\mathrm{kg} / \mathrm{m}^{3}\right)$ & 640 & Total phosphorus (\%) & 0.57 \\
\hline Dry weight $\left(\mathrm{kg} / \mathrm{m}^{3}\right)$ & 460 & Total potassium (\%) & 1.15 \\
\hline Humidity (\%) & 27.8 & $\mathrm{Fe}(\%)$ & 1.26 \\
\hline pH (1:10) & 8.8 & Mn (ppm) & 578 \\
\hline Total nitrogen (\%) & 1.24 & $\mathrm{Cu}$ (ppm) & 136 \\
\hline $\begin{array}{l}\text { Ammonium nitrogen } \\
\text { (ppm) }\end{array}$ & 330 & Zn (ppm) & 130 \\
\hline
\end{tabular}

The Horizontal plots were devoted to three hill spacing $(20,25$ and $30 \mathrm{~cm}$ between hills i.e. 30000,24000 and 20000 plants/fed, respectively).

While, the sub - plots were allocated to four nitrogen fertilizer levels $(50,75,100$ and $125 \mathrm{~kg} \mathrm{~N} / \mathrm{fed})$. Nitrogen fertilizer in the form of urea $(46 \% \mathrm{~N})$ was added as a side-dressing at the previously mentioned levels in two equal 
Leilah, A. A. et al.

parts, one half after thinning (before the first irrigation) and the other half before the second irrigation.

Each experimental basic unit (sub - plot) included five ridges, each of $70 \mathrm{~cm}$ width and $3.0 \mathrm{~m}$ length, resulted an area of $10.5 \mathrm{~m}^{2}$ (1/400 fed). The preceding winter crop was onion (Allium cepa L.) in both seasons.

Soil samples were taken at random from the experimental field area at a depth of $0-30 \mathrm{~cm}$ from soil surface before soil preparation to measure the mechanical and chemical soil properties. Results of mechanical and chemical analysis are presented in Table 1.

Table 2: Mechanical and chemical soil characteristics at the experimental sites during the two growing seasons.

\begin{tabular}{|l|c|c|}
\hline \multicolumn{1}{|c|}{ Soil analysis } & 2006 & 2007 \\
\hline Coarse sand (\%) & 1.52 & 1.65 \\
\hline Fine sand (\%) & 27.27 & 26.61 \\
\hline Silt (\%) & 28.16 & 32.44 \\
\hline Clay (\%) & 41.66 & 38.36 \\
\hline Texture class & clayey & clayey \\
\hline Organic matter (\%) & 1.88 & 1.91 \\
\hline Available nitrogen (ppm) & 25.62 & 26.40 \\
\hline Available phosphate (ppm) & 14.68 & 15.74 \\
\hline Available potassium (ppm) & 316.00 & 338.00 \\
\hline pH & 7.68 & 7.87 \\
\hline EC m. mohs $/{\text { cm at } 25^{\circ} \mathrm{C}}^{\text {C }}$ & 2.33 & 2.76 \\
\hline
\end{tabular}

The experimental field well prepared and then divided into the experimental units. Calcium superphosphate $\left(15.5 \% \mathrm{P}_{2} \mathrm{O}_{5}\right)$ was applied during soil preparation at the rate of $150 \mathrm{~kg} / \mathrm{fed}$. Maize grains were hand sown in hills at the rate of $2-3$ grains/hill using dry sowing method (Afir) on one side of the ridge with the above mentioned hill spacing during the second week of May in 2006 and 2007 seasons. The other agricultural practices were kept the same as normally practiced in maize fields according to the recommendations of Ministry of Agriculture and Land Reclamation, except for the factors under study.

\section{Data recorded:}

A- Growth characters:

1- Number of days from planting to $50 \%$ tasseling was determined of each sub - plot plants.

After 80 days from planting, random samples of ten guarded plants were taken at random from each sub - plot to determine the following growth characters:

2- Plant height $(\mathrm{cm})$.

3- Ear height $(\mathrm{cm})$.

4- Ear leaf area $\left(\mathrm{cm}^{2}\right)$ was calculated by the following formula according to Gardner et al. (1985):

5- Ear leaf area $=$ maximum length $X$ maximum width of ear leaf $X 0.75$ 


\section{B- Yield and its components:}

At harvest (after 120 days from planting) random samples of ten guarded plants were taken at random from each sub - plot to determine the following growth characters:

1- Ear length $(\mathrm{cm})$.

3- Number of grains/row.

5- 100-grain weight (g).

6- Grain yield (ardab/fed); it was determined by the weight of grains per kilograms adjusted to $15.5 \%$ moisture content of each plot, then converted to ardab per feddan.

All data were statistically analyzed according to the technique of analysis of variance (ANOVA) for the strip split - plot design as published by Gomez and Gomez (1984) by means of "MSTAT-C" Computer software package. The treatment means were compared using least significant difference (LSD) method at $5 \%$ levels of probability according to the producer outlined by Waller and Duncan (1969).

\section{RESULTS AND DISCUSSION}

\section{A- Effect of organic fertilization (compost) doses:}

The obtained results obvious that number of days from sowing to 50 $\%$ tasseling, plant height $(\mathrm{cm})$, ear height $(\mathrm{cm})$ and ear leaf area $\left(\mathrm{cm}^{2}\right)$ were significantly affected by organic fertilization (compost) doses in both seasons (Table 3). The highest values of all these characters were obtained by application maize plants with the highest dose of compost ( $4 \mathrm{t} / \mathrm{fed})$. While, the lowest values of above mentioned characters were resulted from control treatment (without organic fertilization) in the first and second seasons. The increase of growth characters due to organic matter may be ascribed to improve soil organic matter, nitrogen content, $\mathrm{P}_{2} \mathrm{O}_{5}$ concentration, exchangeable cations and apart of $\mathrm{Fe}$ and consequently enhancement of plant growth and development as well as yield. These results came in the similar point view with those reported by Toderi et al. (1999).

All yield components and yield i.e. ear length $(\mathrm{cm})$, ear diameter $(\mathrm{cm})$, number of grains/row, ear grains weight $(\mathrm{g})$, 100-grain weight $(\mathrm{g})$ and grain yield (ardab/fed) were significantly improved as a result of applying organic fertilization (compost) doses in both seasons (Table 4). The highest values of these characters were achieved by added $4 \mathrm{t} / \mathrm{fed}$ compost in both seasons. Superiority in grain yield and its components optained by adding 4 or $2 \mathrm{t} / \mathrm{fed}$ of organic matter and its components may be due to the improving action of organic matter on physical, biological and chemical properties of soil. Also, the use of organic matter improved soil c/n ration, nitrogen content, $\mathrm{P}_{2} \mathrm{O}_{5}$ concentration, exchangeable cations and apart of $\mathrm{Fe}$ and consequently enhancement plant growth and development as well as grain yield. The scope of this findings is generally in accordance to those obtained by Fatma, Nofal et al. (2005) and El-Hamdi et al. (2008). 


\section{Leilah, A. A. et al.}




\section{B. Effect of hill spacings (plant population):}

Number of days from sowing to $50 \%$ tasseling and plant height $(\mathrm{cm})$ were significantly increased with decreasing plant spacings $(20 \mathrm{~cm}$ between hills) in both seasons (Table 3). While, ear height $(\mathrm{cm})$ and ear leaf area $\left(\mathrm{cm}^{2}\right)$ were significantly increased by increasing hill spacings $(30 \mathrm{~cm}$ between hills) in both seasons. These results could be attributed to a good utilization of light, nutrients and available water in case of $30 \mathrm{~cm}$ between hills which gave a shorted plants. More, in case of narrow plant spacings $(20 \mathrm{~cm})$ dense plants suffered from light competiton among maize plant. And this hastened stem internodes elongation and consequently length of plant was increased. These results are supported by these of El-Far (2001) and Sharief (2001).

Ear length $(\mathrm{cm})$, ear diameter $(\mathrm{cm})$, number of grains/row, ear grains weight $(\mathrm{g})$ and 100-grain weight $(\mathrm{g})$ were increased by increasing plant spacings (30 $\mathrm{cm}$ between hills), while, grain yield(ardab/fed) decreased in both seasons (Table 4). Increasing plant spacings from 20 to $25 \mathrm{~cm}$ markedly increased grain yield from 28.97 to $30.03 \mathrm{ardab} / \mathrm{fed}$ in the first season, and from 30.64 to $31.54 \mathrm{ardab} / \mathrm{fed}$ in the second season. While, increasing plant spacings from 25 to $30 \mathrm{~cm}$ between hills significantly decreased grain yield/fed up to 26.63 and $28.22 \mathrm{ardab} / \mathrm{fed}$ for the first and second seasons, respectively. Generally, $25 \mathrm{~cm}$ between hills (medium space) surpassed other plant spacings in grain yield (ardab/fed). It was followed by $20 \mathrm{~cm}$ between hills without any significant differences in aforementioned character in the first and second seasons. In spite of the increases in yield components and the reduction in barren stalk percentage by increasing hill spaces, grain yield/fed was decreased, because the increment percentage in yield components did not compensate the decline in number of productive plants, which was in range of recommendation for maize crop. Increasing hill space $(30 \mathrm{~cm})$ did not adequate to utilize the whole area of soil at the optimum density $(30 \mathrm{~cm})$ of maize plants, because this cultivar Single Cross Hybrid Pioneer $30 \mathrm{~K} 9$ does not need a wide space $(30 \mathrm{~cm})$ due to the horizontal growth of their leaves. These results are in good agreement with those obtained by Samira et al. (2000) and Sharief (2001).

C. Effect of nitrogen fertilizer levels:

All growth characters under study were proved to be significant increase as a result of increasing nitrogen fertilizer level, except number of days from sowing to $50 \%$ tasseling which decrease with increasing nitrogen fertilizer level in the first and second seasons (Table 3). Raising nitrogen fertilizer levels from 50 to $125 \mathrm{~kg} \mathrm{~N} /$ fed significantly improved all growth characters such as plant height $(\mathrm{cm})$, ear height $(\mathrm{cm})$ and ear leaf area $\left(\mathrm{cm}^{2}\right)$, while decreased number of days from sowing to $50 \%$ tasseling in both seasons. Increasing nitrogen fertilizer level up to $125 \mathrm{~kg} \mathrm{~N} / \mathrm{fed}$ resulted in highest means of all growth measurements as previously mentioned. Vice versa, maize plants growing with $50 \mathrm{~kg} \mathrm{~N} / \mathrm{fed}$ (lowest nitrogen treatment) were induced the lowest ones in both seasons. 
Leilah, A. A. et al.

T4

1260 
The increase in growth characters with the increase in nitrogen fertilizer levels may be due to the fact that nitrogen is a major nutrient element for meristimic activity which affected the increases in plant growth and development. These findings came of the same point view of ElMahdy,Amal, (2003).

Raising nitrogen fertilizer levels from 50 to $125 \mathrm{~kg} \mathrm{~N} / \mathrm{fed}$ showed a significant increase on all yield components (ear length $(\mathrm{cm})$, ear diameter $(\mathrm{cm})$, number of grains/row, ear grains weight $(\mathrm{g}), 100$-grain weight $(\mathrm{g})$ and grain yield (ardab/fed) as shown in Table 4 . In both seasons, fertilizing maize plants with $125 \mathrm{~kg} \mathrm{~N} / \mathrm{fed}$ gave the highest values of all yield components and grain yield. Moreover, $125 \mathrm{~kg} \mathrm{~N} / \mathrm{fed}$ came in the first rank in grain yield (ardab/fed), while $100 \mathrm{~kg} \mathrm{~N} / \mathrm{fed}$ treatment came in the second rank in the previously mentioned characters without significant differences between them in both seasons. This increase in grain yield and its components by increasing nitrogen fertilizer levels might be due to the improvement in plant growth and leaf chlorophyll content which reflected in turn increase in the different yield components. Similar observation was reported by Atia and Mahmoud (2006), Seadh and El-Zehery (2007) and El-Hamdi et al. (2008).

\section{IV- Effect of interaction:}

Regarding the effect of interactions, it could be noticed that grain yield (ardab/fed) was significantly influenced by the various ways of interaction during both seasons, except the interaction among the three factors in both seasons.

A significant interaction effect between organic fertilization (compost) doses $X$ hill spacings on grain yield (ardab/fed) during the first and second seasons. It is great attention to expect that the highest grain yield (34.33 and $36.36 \mathrm{ardab} / \mathrm{fed}$ ) were obtained by adding $4 \mathrm{t} / \mathrm{fed}$ compost and sowing maize plants at $25 \mathrm{~cm}$ distance between hills in the first and second seasons, respectively (Fig. 1). It was followed by $2 \mathrm{t} / \mathrm{fed}$ compost and sowing maize plants at $20 \mathrm{~cm}$ distance between hills without significant differences in aforementioned character in both seasons.

Fig.2 indicated that the interaction between organic fertilization (compost) doses $\mathrm{X}$ nitrogen fertilizer levels had a significant effects on grain yield(ardab/fed.) weight in both seasons. Grain yield significantly increased with every increase in compost doses under all nitrogen levels. The highest values of grain yield ( 35.24 and 37.36 ardab/fed) were obtained with adding 4 t/fed compost and fertilized maize plants with $125 \mathrm{~kg} \mathrm{~N} / \mathrm{fed}$ in the first and second seasons, respectively (Fig. 2). It was followed by using $4 \mathrm{t} / \mathrm{fed}$ compost and $100 \mathrm{~kg} \mathrm{~N} / \mathrm{fed}$ without significant differences in aforementioned character in both seasons.

Grain yield (ardab/fed) was significantly affected by the interaction between hill spacings $X$ nitrogen fertilizer levels in both seasons. Data graphically illustrated in Fig. 3 appear that the maximum values of grain yield were obtained from sowing maize plants at $25 \mathrm{~cm}$ between hills and adding $125 \mathrm{~kg} \mathrm{~N} / \mathrm{fed}$, which yielded 32.26 and $34.60 \mathrm{ardab} / \mathrm{fed}$ in the first and second seasons, respectively.

It can be concluded that sowing maize Single Cross Pioneer $30 \mathrm{~K} 9$ plants at $25 \mathrm{~cm}$ space between hills (24 000 plant/fed) and adding $4 \mathrm{t} / \mathrm{fed}$ 
compost as well as 100 or $125 \mathrm{~kg} \mathrm{~N} / \mathrm{fed}$ can be used as arecommended treatment to maximize maize productivity under the environmental conditions of El-Mansoura region.

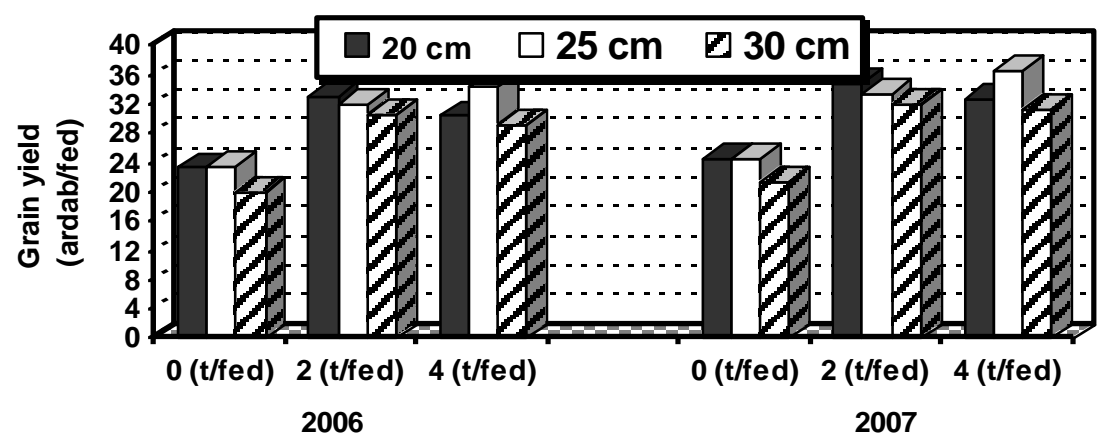

Fig. 1: Maize grain yield (ardab/fed) as affected by the interaction between organic fertilization (compost) doses and hill spacings during 2006 and 2007 seasons.

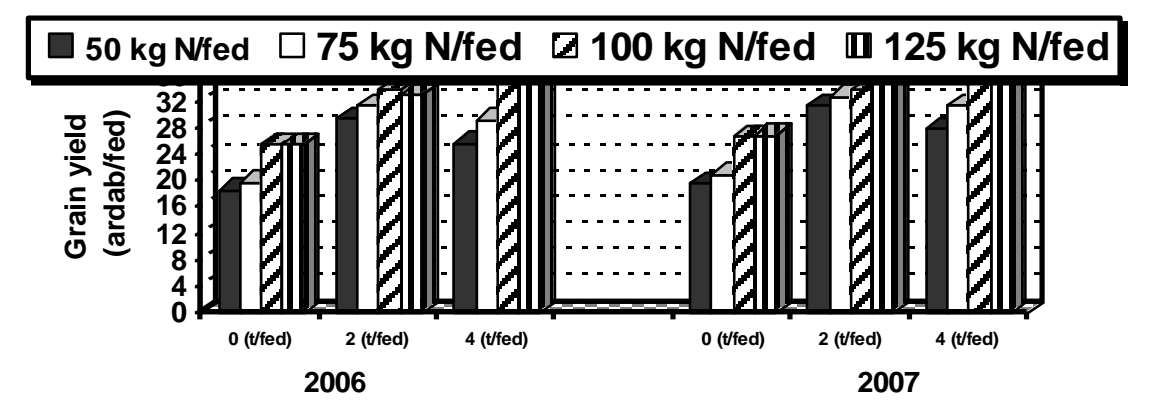

Fig. 2: Maize grain yield (ardab/fed) as affected by the interaction between organic fertilization (compost) doses and nitrogen fertilizer levels during 2006 and 2007 seasons.

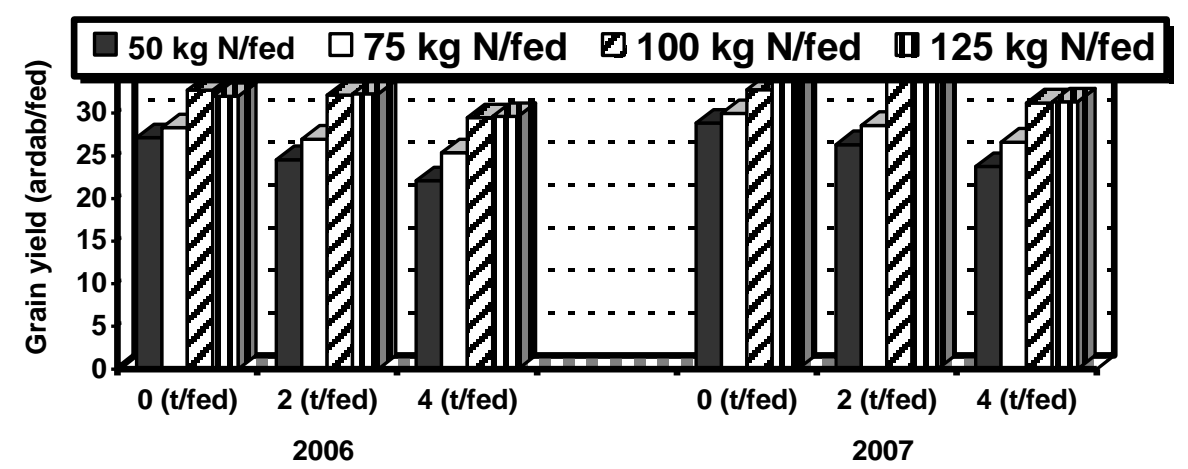

Fig. 3: Maize grain yield (ardab/fed) as affected by the interaction between hill spacings and nitrogen fertilizer levels during 2006 and 2007 seasons. 


\section{REFERENCES}

Abd-Alla, A.A. (2005). Maize yield potentiality in response to bio and mineral nitrogen fertilizer under drip irrigation regimes in the newly reclaimed soils. J. Agric. Sci. Mansoura Unv., 30 (10): 5765-5779.

Abdel-Hafez, S.A. ; H.A. Meshref ; Kh.H. El-Hamdi and Gh.Sh. El-Atawy (2008). Effect of irrigation, nitrogen and organic fertilization on soil water relationships of maize crop. J. Agric. Sci. Mansoura Univ., 33(7): 5409-5418.

Ali, K.M.L. ; Wafaa, .T. El-Etr and Elham, I. El-khatib (2003). Evaluation of application of bacterial inoculation for rice straw during compost process under aerobic conditions. J. Agric. Sci. Mansoura Univ., 28: 5787-5801.

Atia, A.A. and A.A. Mahmoud (2006). Economic study to evaluate the nitrogen response curve in maize. J. Agric. Sci. Mansoura Univ., 31(4): 1837-1846.

Cox, W.J. and D.J. Cherney (2001) Row spacing, plant density and nitrogen effect on corn silage. Agron. J., 93: 597-602.

El-Far, H.A.R. (2001). Agronomic studies on maize. Ph. D. Thesis, in Agron., Fac. of Agric. Mansoura Univ.

El-Hamdi, Kh.H. ; H.A. Meshref ; S.A. Abdel-Hafez and Gh.Sh. El-Atawy (2008). Effect of irrigation, nitrogen and organic fertilization on yield and nutrient contents of maize crop. J. Agric. Sci. Mansoura Univ., 33(7): 5419-5428.

El-Mahdy, Amal A.A. (2003). Response of maize plants (Zea mays L.) to some agronomic treatments and fertilization with both nitrogen and biological fertilizer. M. Sc. Thesis, in Agron., Fac. of Agric. Mansoura Univ.

El-Murshedy, W.A. (2002). Response of some maize cultivars to nitrogen fertilization under two farming system. J. Agric. Sci. Mansoura Univ., 27(5): 2821-2835.

Fatma, A.E. Nofal ; M.S.M. Soliman and M.M. Abdel-Ghani (2005). Effect of irrigation at different water depletions levels, nitrogen and manure applications on water use efficiency and maize grain yield in sandy soils. Minufiya J. Agric. Res., 30(1): 1159-1177.

Gardner, F.P. ; R.B. Pearce and R.L. Michell (1985). Physiology of crop plant. lowa State Univ. Press Ames. lowa. USA pp. 58-75.

Gomez, K.N. and A.A. Gomez (1984). Statistical Procedures for Agricultural Research. John Wiley and Sons, New York, 2nd ed., 68 p.

Salem, N. (1988). Evaluation of some parameters influencing the use of conditioners in soils. Inter. Symp. Soil Conditioner, Egypt, pp. 81-91.

Samira, M.A. Hussein (2005). Optimizing utilization of nitrogen fertilizer under same intercropping system of groundnut and maize in sandy soil. J. Agric. Sci. Mansoura Univ., 30(9): 4979-4989.

Samira, M.A. Hussein ; M.A.H. Haikle and A.M. Melegy (2000). Effect of water requirements and plant densities on yield and its attributes of corn (Zea mays L.) under drip irrigation system in new reclaimed soil in North Sinai. J. Agric. Sci. Mansoura Univ., 25 (5): 2439-2448.

Schroder, J.I. ; J.J. Neetesona ; O. Oenemaa and P.C. Struik (2000). Does the crop or the soil indicate how to save nitrogen in maize production, Reviewing the state of the art. Field Crops Res., 66: 151-164.

Seadh, S.E. and T.M. El-Zehery (2007). Integrated effect of mineral nitrogen fertilization and organic matter extract on maize productivity. Arab Conf. of Soil and Water Management for Sustainable Agricultural Development, Fac. of Agric. Mansoura Univ., 10-11 th April 2007, Mansoura, Egypt, pp. 435-443. 
Leilah, A. A. et al.

Sharief, A.E.M. (2001). Plant population density as limited factor affecting production of cereal crops. J. Agric. Sci. Mansoura Univ., 26(3): 12191245.

Sheng Mao, Y. ; L. Feng Min ; G. Tian Wen ; W. Jian Guo ; S. Bing Ling and J. Shao Ling (2006). Effect of long term fertilization on soil productivity and nitrate accumulation in Gansu Oasis, China. Agric. Sci. in China, 5 (1): 57-67.

Toaima, S.E.A. and S.A. Saleh (2003). Yield and yield components of maize and sunflower as affected by preceding crop and $\mathrm{N}-$ fertilizer levels. $\mathrm{J}$. Agric. Sci. Mansoura Univ., 28(4): 2467-2476.

Toderi, G. ; G. Giordam ; F. Comellini and M. Guermandi (1999). Effects of organic materials utilization and nitrogen fertilization on soil fertility. Rivista de Agronomia, 33 (1): 1-7 (Computer Search).

Waller, R.A. and D.B. Duncan (1969). A bays rule for the symmetric multiple comparison problem. J. Amer. Assoc., 64: 1484-1503.

\footnotetext{
تأثير الكثافة النباتية والتسميد العضوى ومستويات النيتروجين على نمو ومحصول

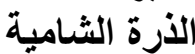

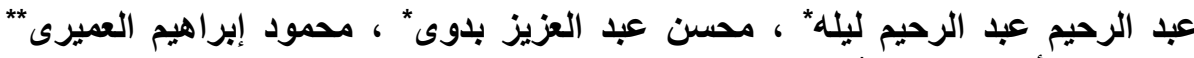
ورشا سعد أحمد المرسى الرحئ

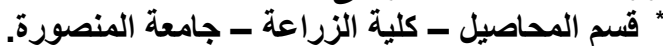

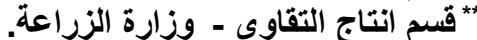

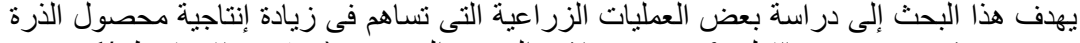

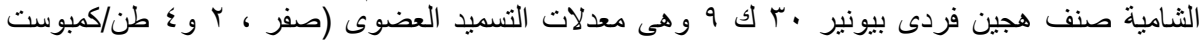

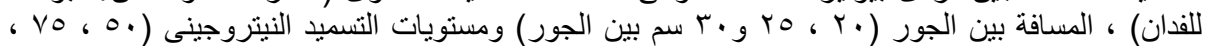

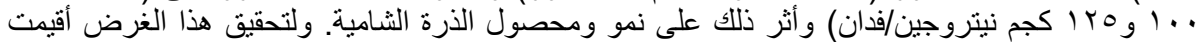

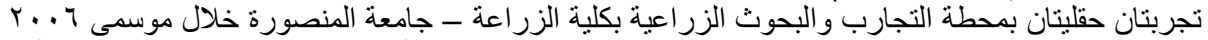

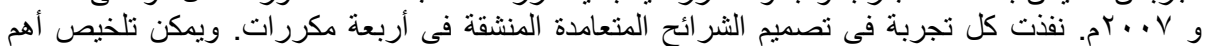
أظهرت النتائج المتحصل عليها أن جميع صفات النمو و الدحصول و مكوناته تحت الدراسة قد الد الدئ

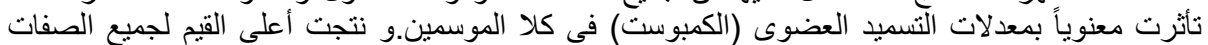

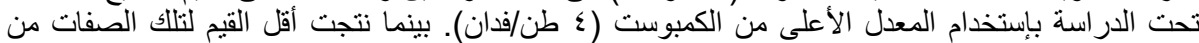
معاملة المقارنة بدون تسميد عضوى الزئل في كلا الموسمين.

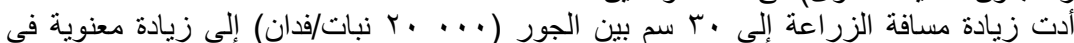

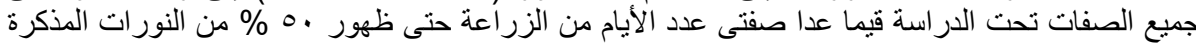

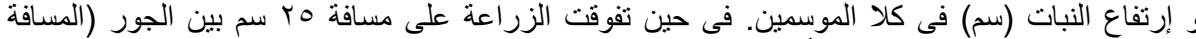

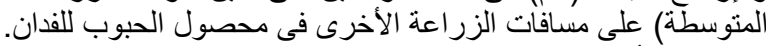

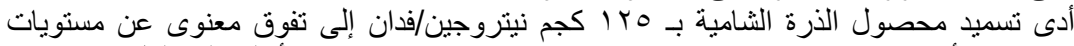

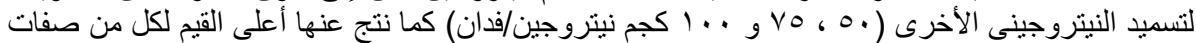

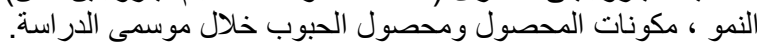

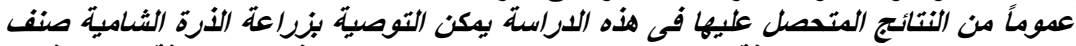

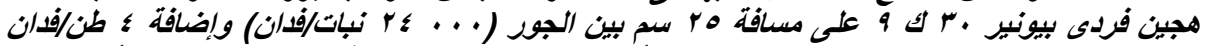

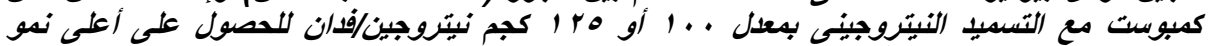
ومحصول تحت ظروف منطقة المنصورة.
} 
J. Agric. Sci. Mansoura Univ., 34 (2), February, 2009 
Table 3: Number of days from sowing to $50 \%$ tasseling, plant height $(\mathrm{cm})$, ear height $(\mathrm{cm})$ and ear leaf area $\left(\mathrm{cm}^{2}\right)$ as affected by organic fertilization (compost) doses, hill spacings and nitrogen fertilizer levels during 2006 and 2007 seasons.

\begin{tabular}{|c|c|c|c|c|c|c|c|c|}
\hline \multirow{2}{*}{$\overbrace{\text { Treatments }}$ Cha } & \multicolumn{2}{|c|}{$\begin{array}{c}\text { No. of days from sowing } \\
\text { to } 50 \% \text { tasseling }\end{array}$} & \multicolumn{2}{|c|}{$\begin{array}{l}\text { Plant height } \\
\text { (cm) }\end{array}$} & \multicolumn{2}{|c|}{$\begin{array}{l}\text { Ear height } \\
\quad(\mathrm{cm})\end{array}$} & \multicolumn{2}{|c|}{$\begin{array}{l}\text { Ear leaf area } \\
\left(\mathrm{cm}^{2}\right)\end{array}$} \\
\hline & 2006 & 2007 & 2006 & 2007 & 2006 & 2007 & 2006 & 2007 \\
\hline \multicolumn{9}{|c|}{ A- Organic fertilization (compost) doses: } \\
\hline 0 (t/fed) Control & 57.6 & 58.6 & 260.3 & 291.7 & 128.4 & 147.7 & 681.8 & 692.9 \\
\hline $2(\mathrm{t} / \mathrm{fed})$ & 58.3 & 59.1 & 266.6 & 297.2 & 130.7 & 151.5 & 714.1 & 713.7 \\
\hline $4(\mathrm{t} / \mathrm{fed})$ & 58.9 & 59.8 & 287.6 & 303.7 & 133.2 & 154.5 & 718.4 & 805.8 \\
\hline F. test & * & * & * & * & * & * & * & * \\
\hline LSD $5 \%$ & 0.16 & 0.20 & 1.1 & 0.6 & 0.5 & 0.5 & 9.4 & 6.1 \\
\hline \multicolumn{9}{|c|}{ B- Hill spacings $(\mathrm{cm}):$} \\
\hline 20 & 58.6 & 59.6 & 279.6 & 300.9 & 128.0 & 148.6 & 696.3 & 725.3 \\
\hline 25 & 58.2 & 59.2 & 271.2 & 297.7 & 131.0 & 151.5 & 705.3 & 737.7 \\
\hline 30 & 57.8 & 59.8 & 263.8 & 293.9 & 133.2 & 153.7 & 712.7 & 749.4 \\
\hline F. test & * & * & * & * & * & * & * & * \\
\hline LSD $5 \%$ & 0.13 & 0.07 & 1.9 & 1.3 & 0.4 & 0.7 & 6.5 & 2.5 \\
\hline \multicolumn{9}{|c|}{ C- Nitrogen fertilizer levels: } \\
\hline $50 \mathrm{~kg} \mathrm{~N} / \mathrm{fed}$ & 59.8 & 60.1 & 261.5 & 292.0 & 126.6 & 147.2 & 695.7 & 718.4 \\
\hline $75 \mathrm{~kg} \mathrm{~N} / \mathrm{fed}$ & 58.4 & 59.5 & 268.1 & 295.4 & 129.6 & 149.8 & 698.7 & 734.7 \\
\hline $100 \mathrm{~kg} \mathrm{~N} / \mathrm{fed}$ & 58.1 & 58.8 & 276.0 & 299.3 & 131.9 & 152.8 & 706.8 & 742.8 \\
\hline $125 \mathrm{~kg} \mathrm{~N} / \mathrm{fed}$ & 57.6 & 58.3 & 280.6 & 303.4 & 134.9 & 155.1 & 717.8 & 754.0 \\
\hline F. test & * & * & * & * & * & * & * & * \\
\hline LSD $5 \%$ & 0.14 & 0.15 & 3.3 & 1.1 & 0.6 & 0.7 & 5.5 & 4.1 \\
\hline
\end{tabular}


Table 4: Ear length and diameter $(\mathrm{cm})$, number of grains/row, ear grains weight $(\mathrm{g}), 100$-grain weight $(\mathrm{g})$ and grain yield (ardab/fed) as affected by organic fertilization (compost) doses, hill spacings and nitrogen fertilizer levels during 2006 and 2007 seasons.

\begin{tabular}{|c|c|c|c|c|c|c|c|c|c|c|c|c|}
\hline \multirow{2}{*}{ Characters } & \multicolumn{2}{|c|}{ Ear length (cm) } & \multicolumn{2}{|c|}{$\begin{array}{l}\text { Ear diameter } \\
(\mathrm{cm})\end{array}$} & \multicolumn{2}{|c|}{$\begin{array}{l}\text { Number of } \\
\text { grains/row }\end{array}$} & \multicolumn{4}{|c|}{\begin{tabular}{|c|c|}
$\begin{array}{c}\text { Ear grains weight } \\
(\mathrm{g})\end{array}$ & $\begin{array}{c}100 \text {-grain weight } \\
(\mathrm{g})\end{array}$
\end{tabular}} & \multicolumn{2}{|c|}{$\begin{array}{l}\text { Grain yield } \\
\text { (ardab/fed) }\end{array}$} \\
\hline & 2006 & 2007 & 2006 & 2007 & 2006 & 2007 & 2006 & 2007 & 2006 & 2007 & 2006 & 2007 \\
\hline \multicolumn{13}{|c|}{ A- Organic fertilization (compost) doses: } \\
\hline 0 (t/fed) Control & 18.61 & 19.56 & 3.91 & 4.09 & 40.44 & 43.29 & 188.8 & 200.8 & 37.42 & 37.10 & 22.39 & 23.54 \\
\hline $2(\mathrm{t} / \mathrm{fed})$ & 18.92 & 21.18 & 4.21 & 4.53 & 42.47 & 44.59 & 199.6 & 212.7 & 39.79 & 39.46 & 31.32 & 33.35 \\
\hline $4(\mathrm{t} /$ fed $)$ & 19.50 & 22.86 & 4.59 & 5.10 & 43.23 & 45.73 & 207.6 & 223.3 & 43.74 & 43.49 & 31.92 & 33.52 \\
\hline F. test & $*$ & $*$ & * & * & * & 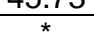 & $*$ & $*$ & $\frac{40.14}{*}$ & $\frac{40.40}{*}$ & $*$ & $*$ \\
\hline LSD $\quad 5 \%$ & 0.17 & 0.09 & 0.10 & 0.17 & 0.27 & 0.22 & 1.4 & 1.5 & 0.21 & 0.16 & 1.38 & 1.36 \\
\hline \multicolumn{13}{|c|}{ B- Hill spacings (cm): } \\
\hline 20 & 18.47 & 20.53 & 4.03 & 4.27 & 40.80 & 43.71 & 193.3 & 207.2 & 39.03 & 38.71 & 28.97 & 30.64 \\
\hline 25 & 18.98 & 21.19 & 4.20 & 4.59 & 42.31 & 44.41 & 199.4 & 212.9 & 40.27 & 39.94 & 30.03 & 31.54 \\
\hline 30 & 19.58 & 21.88 & 4.47 & 4.85 & 43.03 & 45.48 & 203.3 & 216.8 & 41.65 & 41.40 & 26.63 & 28.22 \\
\hline F. test & * & * & * & * & * & * & * & * & * & * & * & * \\
\hline LSD $5 \%$ & 0.10 & 0.13 & 0.11 & 0.11 & 0.26 & 0.17 & 1.9 & 1.6 & 0.22 & 0.32 & 1.77 & 2.01 \\
\hline \multicolumn{13}{|c|}{ C- Nitrogen fertilizer levels: } \\
\hline $50 \mathrm{~kg} \mathrm{~N} / \mathrm{fed}$ & 18.56 & 20.61 & 4.02 & 4.29 & 40.74 & 42.83 & 191.7 & 207.1 & 39.47 & 39.12 & 24.59 & 26.30 \\
\hline $75 \mathrm{~kg} \mathrm{~N} / \mathrm{fed}$ & 18.82 & 21.05 & 4.19 & 4.49 & 41.80 & 44.40 & 197.4 & 210.8 & 40.00 & 39.71 & 26.87 & 28.38 \\
\hline $100 \mathrm{~kg} \mathrm{~N} /$ fed & 19.16 & 21.46 & 4.28 & 4.69 & 42.68 & 45.35 & 202.4 & 215.5 & 40.83 & 40.57 & 31.29 & 32.59 \\
\hline $125 \mathrm{~kg} \mathrm{~N} / \mathrm{fed}$ & 19.51 & 21.69 & 4.45 & 4.81 & 42.97 & 45.55 & 203.3 & 215.8 & 40.97 & 40.65 & 31.42 & 33.27 \\
\hline F. test & * & $*$ & * & * & * & * & * & * & * & $*$ & $\star$ & * \\
\hline LSD $5 \%$ & 0.18 & 0.12 & 0.19 & 0.16 & 0.75 & 0.53 & 2.6 & 1.6 & 0.27 & 0.27 & 1.00 & 1.21 \\
\hline
\end{tabular}

